\title{
BEBERAPA SIFAT KIMIA TANAH SAWAH ATAS PENGGUNAAN PUPUK ORGANIK DENGAN KURUN WAKTU BERBEDA DI SAYEGAN, SLEMAN
}

\section{SOME CHEMICAL PROPERTIES OF PADDY SOIL ON THE ORGANIC FERTILIZER APPLICATIONS WITH DIFFERENT PERIODS IN SEYEGAN, SLEMAN}

\author{
Tri Mulyadi ${ }^{1)}$, M. Nurcholis ${ }^{2 * *)}$, Partoyo $^{2)}$ \\ ${ }^{1)}$ Prodi Agroteknologi, Universitas Pembangunan Nasional Veteran Yogyakarta \\ ${ }^{2)}$ Prodi Ilmu Tanah, Universitas Pembangunan Nasional Veteran Yogyakarta \\ ${ }^{*}$ Corresponding author E - mail: nurcholis@upnyk.ac.id
}

\begin{abstract}
The application of organic fertilizers in the short or long term to the paddy soil may have an effect on increasing the organic matter of the paddy soil, thus affecting the availability of soil nutrients. The purpose of this study was to determine some of the chemical properties of paddy soil in different organic fertilizers for the time period. The research was conducted in rice field of Latosol in Margoluwih Village, Sayegan District, Sleman Regency, on paddy fields that had been fertilized organically for different periods of time, namely: 3, 7, and 13 years. Soil samples were collected at the seven sites in each different periods at a depth of 0-20 cm. The soil chemical properties analyzed were $\mathrm{pH}(\mathrm{H} 2 \mathrm{O}$ and $\mathrm{KCl})$, Electrical Conductivity (DHL), Redox Potential (Eh), C-Organic, P-Available, K-Available, N-Total. The mean difference between treatments for each parameter in the t-test was at the level of $\alpha=5 \%$. The results showed that the treatment of organic fertilizers increased the highest average value of C-Organic, Available K, and Total $\mathrm{N}$ of soil in continuous application for 13 years.
\end{abstract}

Keywords: Organic Fertilizer, Paddy Soil, Chemical Properties of Soil.

\begin{abstract}
ABSTRAK
Pemberian pupuk organik dalam jangka pendek atau jangka panjang ke tanah sawah dapat berpengaruh terhadap peningkatan bahan organik tanah sawah, sehingga berpengaruh terhadap ketersediaan unsur hara tanah sawah. Tujuan dari penelitian ini adalah untuk mengetahui beberapa sifat kimia tanah sawah pada pemberian pupuk organik yang berbeda kurun waktunya. Penelitian dilakukan di tanah sawah jenis Latosol di Desa Margoluwih, Kecamatan Sayegan, Kabupaten Sleman, di tanah sawah yang sudah dipupuk organik selama kurun waktu berbeda, yaitu: 3, 7, dan 13 tahun. Pengambilan sampel tanah di ketiga lokasi penelitian dilakukan di kedalaman 0-20 cm. Sifat kimia tanah yang dianalisis adalah $\mathrm{pH}\left(\mathrm{H}_{2} \mathrm{O}\right.$ dan $\left.\mathrm{KCl}\right)$, Daya Hantar Listrik (DHL), Potensial Redoks (Eh), C- Organik, P-Tersedia, K-Tersedia, N-Total. Beda rerata antar perlakuan untuk setiap parameter di Uji t-Test pada taraf $\alpha=5 \%$. Hasil penelitian menunjukkan perlakuan pupuk organik meningkatkan nilai rerata tertinggi C-Organik, K Tersedia, dan $\mathrm{N}$ Total tanah pada pemberian kontinyu selama 13 tahun.
\end{abstract}

Kata kunci: Pupuk Organik, Tanah Sawah, Sifat Kimia Tanah. 


\section{PENDAHULUAN}

Selama ini para petani sering menggunakan pupuk anorganik untuk memenuhi kebutuhan bercocok tanam tanaman budidaya secara terus menerus dan berlangsung dalam jangka waktu yang lama. Akibatnya, kebiasaan ini menyebabkan turunnya kualitas lahan dengan ditandai turunnya kandungan bahan organik tanah dan kemampuan tanah untuk menyimpan dan melepaskan unsur hara, sehingga produktivitas lahan menurun. Dampak lain penggunaan pupuk kimia yang berlebihan adalah dapat mengakibatkan pencemaran lingkungan (Suriadarma, 2011). Untuk memperbaiki kondisi tanah diperlukan proses pembenahan. Proses pembenah tanah suatu lahan sawah dengan penggunaan pupuk organik memerlukan waktu yang cukup lama. Salah satu upaya untuk memperbaiki kondisi tanah adalah dengan menggunakan pupuk organik secara menerus beberapa tahun (Siregar dan Hartatik, 2010). Sumber bahan organik ini dapat berasal dari pengomposan sisa tanaman atau kotoran hewan. Senyawa organik yang terkandung dalam pupuk organik dapat berinteraksi dengan baik dengan komponen abiotik dan biotik dalam ekosistem tanah (Zahrah, 2011). Bahan organik selain dapat berfungsi sebagai sumber hara, juga dapat berfungsi sebagai pembenah tanah dalam jangka waktu panjang. Aplikasi pupuk organik ke dalam tanah selain ditujukan sebagai sumber hara makro, mikro, dan asam-asam organik, juga berperan untuk memperbaiki kesuburan fisik, kimia dan biologi tanah.

Hasil percobaan pemupukan secara nasional di China menunjukkan bahwa penggunaan pupuk organik secara rasional jangka panjang meningkatkan kesuburan tanah, seperti peningkatan kadar bahan organik, kadar N, P, dan K khususnya tanah-tanah miskin (Gong et al., 2009). Kadar bahan organik tanah meningkat dalam sistem penanaman yang berbeda setelah penggunaan pupuk jangka panjang (10 tahun), baik untuk sumber pupuk organik maupun anorganik (Roidah, 2013).

Informasi mengenai suatu tanah sangat diperlukan, untuk itu diperlukan adanya pengetahuan tentang sifat-sifat tanah (terutama sifat kimia) dan informasi penting mengenai potensi tanah serta penggunakaan tanah yang efisien. Hal ini dapat diperoleh dengan melakukan survei tanah di lapangan dan kemudian dilanjutkan dengan analisa di laboratorium.

Tujuan dari penelitian ini adalah untuk mengetahui sifat kimia tanah sawah yang berubah di Desa Margoluwih, Kecamatan Seyegan, Kabupaten Sleman atas aplikasi pupuk organik yang memiliki masa waktu berbeda.

\section{BAHAN DAN METODE}

Penelitian ini dilakukan di tanah jenis Latosol lahan sawah di Desa Margoluwih, Kecamatan Seyegan, Kabupaten Sleman, Yogyakarta. Pertama, yang digunakan dalam penelitian kali ini adalah melakukan survei dengan tujuan mendapatkan informasi tentang aplikasi pupuk organik di lahan sawah di desa tersebut. Pengamatan lapangan dilakukan untuk mendeskripsikan perbedaan pada pemupukan tanah sawah dengan pupuk organik pada kurun waktu yang berbeda, dengan pemilik yang berbeda. Lokasi (A) diambil di lokasi yang berada pada lahan dengan masa penggunaan pupuk organik selama 13 tahun, lokasi yang kedua (B) dengan masa selama 7 tahun, dan lokasi yang ketiga (C) dengan masa selama 3 tahun. Ketiga lokasi berdampingan satu dengan lainnya, dengan mendapatkan air irigasi dari sumber saluran irigasi yang sama. Batas petak diukur 
koordinat di setiap sudut petak menggunakan GPS (global positioning system). Penetapan jumlah sampel tanah di masing-masing perlakuan dengan tujuh titik dilakukan dengan metode zigzag sampling untuk membuat sampel yang mewakili. Penelitian dilakukan dengan pengambilan sampel tanah dilakukan pada kedalaman tanah sampai $20 \mathrm{~cm}$. Semua sampel tanah dikeringanginkan dan ditumbuk dan diayak lolos saring $2 \mathrm{~mm}$ untuk persiapan analisis tanah. Analisis kimia tanah dilakukan di Laboratorium Tanah di Balai Pengkajian Teknologi Pertanian (BPTP) Yogyakarta., pH dan Eh meter, timbangan, EC meter, air bebas ion (aquades) $\mathrm{H}_{2} \mathrm{O}$ dan $\mathrm{KCl}$. Parameter yang di amati antara lain: $\mathrm{C}$ Organik total tanah menggunakan metode Walkley dan Black, $\mathrm{pH}$ tanah dengan pengekstrak $\mathrm{H}_{2} \mathrm{O}$ (kemasaman tanah aktual) dan $\mathrm{KCl}$ (kemasaman tanah potensial) dengan perbandingan tanah dengan pengekstrak 1:2,5, P-Tersedia dengan ekstrak Bray1 dan ditetapkan menggunakan spektrofotometer, K-Tersedia dengan pengestrak Morgan-Wolf dan ditetapkan menggunakan flame fotometer, N- Total ditetapkan dengan metode Kjeldahl, Daya hantar listrik (DHL) tanah dianalisis menggunakan EC-meter, juga potensial redoks (Eh) menggunakan Eh-meter, di tanah dengan kondisi tanah asli di lahan sawah. Analisis statistic data dilakukan menggunakan analisis keragaman dengan Aplikasi SAS (Statistical Analysis System) pada aras kepercayaan 5\%. Beda antar perlakuan untuk setiap parameter di Uji menurut T-test $\alpha=0,05$.

\section{HASIL DAN PEMBAHASAN}

\section{A. Perubahan Reaksi Tanah.}

\section{1. pH Tanah aktual}

Tabel 1 menunjukkan nilai kemasaman aktual masing-masing titik sample dan rerata yang ditunjukkan oleh $\mathrm{pH}\left(\mathrm{H}_{2} \mathrm{O}\right)$ tanah pada perlakuan $\mathrm{A}=13$ tahun dan $\mathrm{C}=3$ tahun tiap perlakuan tidak berbeda nyata sekaligus juga termasuk dalam harkat agak masam yakni 5,68 dan 5,78 menurut pengharkatan BPT (2009), sedangkan nilai rerata $\mathrm{pH}\left(\mathrm{H}_{2} \mathrm{O}\right)$ tanah pada perlakuan $\mathrm{B}=7$ tahun terjadi perbedaan nyata dengan perlakuan $\mathrm{A}=13$ tahun dan $\mathrm{C}=3$ tahun sekaligus termasuk dalam harkat masam yakni 5,37 menurut pengharkatan BPT (2009). Untuk nilai rerata $\mathrm{pH}\left(\mathrm{H}_{2} \mathrm{O}\right)$ tertinggi terdapat pada perlakuan $\mathrm{C}=5,78$ dan nilai rerata $\mathrm{pH}\left(\mathrm{H}_{2} \mathrm{O}\right)$ terendah terdapat pada perlakuan $\mathrm{B}=5,37$.

Tabel 1. Nilai $\mathrm{pH}\left(\mathrm{H}_{2} \mathrm{O}\right)$ tanah sawah dengan perlakuan perbedaan kurun waktu aplikasi pupuk organik

\begin{tabular}{|c|c|c|c|c|c|c|c|c|c|c|}
\hline \multirow{2}{*}{$\begin{array}{c}\text { Pupuk } \\
\text { organik } \\
\text { selama }\end{array}$} & \multicolumn{7}{|c|}{ pH $\left(\mathrm{H}_{2} \mathrm{O}\right)$ tanah Sampel } & \multirow{2}{*}{$\overline{\boldsymbol{x}}$} & \multirow{2}{*}{$\mathbf{S}$} & \multirow{2}{*}{$\begin{array}{c}\text { Harkat Menurut } \\
\text { BPT }\end{array}$} \\
\hline & 1 & 2 & 3 & 4 & 5 & 6 & 7 & & & \\
\hline A (13 tahun) & 5.92 & 5.77 & 5.49 & 5.67 & 5.81 & 5.67 & 5.54 & $5.70 \mathrm{a}$ & 0.14 & agak masam \\
\hline B (7 tahun) & 6.16 & 5.55 & 5.53 & 5.01 & 5.09 & 5.14 & 5.2 & $5.38 \mathrm{~b}$ & 0.41 & masam \\
\hline $\mathrm{C}$ (3 tahun) & 5.78 & 5.58 & 5.74 & 5.78 & 5.83 & 5.88 & 5.92 & $5.79 a$ & 0.11 & agak masam \\
\hline \multicolumn{11}{|c|}{$\begin{array}{r}\text { Keterangan: } \mathrm{A}=\text { Tanah dengan masa penggunaan pupuk organik selama } 13 \text { tahun; } \mathrm{B}=\text { Tanah } \\
\text { dengan masa penggunaan pupuk organik selama } 7 \text { tahun; } \mathrm{C}=\text { Tanah dengan } \\
\text { masa penggunaan pupuk organik selama } 3 \text { tahun; } \mathrm{X}=\text { Rata-rata nilai sampel; } \mathrm{S} \\
\text { = Standar deviasi sampel. Hasil yang diikuti huruf yang sama dalam kolom } \\
\text { menunjukkan tidak ada beda nyata pada Uji t-Test SAS pada taraf 5\% }\end{array}$} \\
\hline
\end{tabular}


Dari hasil rerata tiap perlakuan $\mathrm{pH}\left(\mathrm{H}_{2} \mathrm{O}\right)$ tanah termasuk ke dalam harkat (agak masam dan masam). Hal ini disebabkan karena bahan organik yang diberikan pada lahan masih mengalami proses dekomposisi sehingga masih menghasilkan asamasam organik, proses ini sejalan dengan aplikasi pupuk kandang yang diberikan petani ke lahan. Rata-rata petani memberikan pupuk organik di lahan dalam kondisi pupuk kandang belum matang secara sempurna sehingga masih mengalami proses dekomposisi. Menurut Muddarisna dan Sugeng (2009) penambahan bahan organik yang belum masak (misal pupuk hijau) atau bahan organik yang masih mengalami proses dekomposisi, biasanya akan menyebabkan penurunan $\mathrm{pH}$ tanah, karena selama proses dekomposisi akan melepaskan asam- asam organik yang menyebabkan menurunnya $\mathrm{pH}$ tanah. Selain itu rendahnya harkat $\mathrm{pH}\left(\mathrm{H}_{2} \mathrm{O}\right)$ tanah juga dipengaruhi oleh proses pencucian basa-basa oleh air pada saat penggenangan lahan sehingga menyebabkan $\mathrm{pH}\left(\mathrm{H}_{2} \mathrm{O}\right)$ tanah menjadi masam. Dengan menurunnya tinggi muka air oleh proses drainase maka suasana menjadi lebih oksidatif sehingga $\mathrm{pH}\left(\mathrm{H}_{2} \mathrm{O}\right)$ tanah mengalami penurunan namun tidak drastis. Perubahan $\mathrm{pH}\left(\mathrm{H}_{2} \mathrm{O}\right)$ ini disebabkan oleh beberapa faktor, diantaranya yaitu perubahan ferri menjadi ion $\mathrm{Fe}^{2+}$, akumulasi amonium, perubahan sulfat menjadi sulfida, dan perubahan karbon dioksida menjadi metana dalam kondisi reduksi sehingga kondisi tanah menjadi sangat reduktif dan peningkatan $\mathrm{pH}$ tanah akibat pembebasan $\mathrm{OH}^{-}$dan konsumsi $\mathrm{H}^{+}$yang diikuti dengan penurunan aktivitas dari $\mathrm{H}^{+}$(Annisa, 2014).

Gambar 1 menunjukkan nilai rerata $\mathrm{pH}$ tanah terendah terdapat pada perlakuan tanah dengan menggunakan pupuk organik $\mathrm{B}=7$ tahun sedangkan nilai rerata $\mathrm{pH}$ tanah tertinggi terdapat pada perlakuan tanah dengan menggunakan pupuk organik $\mathrm{C}=3$ tahun. Terjadinya penurunan nilai rerata $\mathrm{pH}$ tanah $\mathrm{C}=3$ tahun ke $\mathrm{B}=7$ tahun. Ini sesuai dengan pernyataan dari Utami dan Handayani (2003) bahwa waktu 5 tahun belum cukup mempengaruhi sifat dakhil tanah, yang paling terpengaruh adalah larutan tanah.

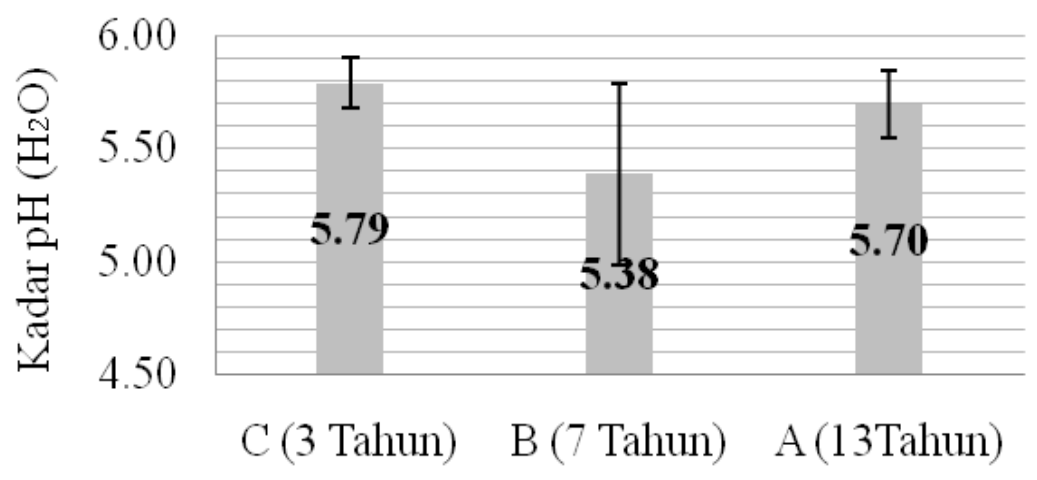

Gambar 1. Rata-rata dan Standar deviasi nilai $\mathrm{pH}\left(\mathrm{H}_{2} \mathrm{O}\right)$ tanah dengan perlakuan penggunaan pupuk organik yang berbeda.

Namun jika dibandingkan dengan $\mathrm{pH}$ tanah pada penggunaan pupuk Organik dengan kurun waktu diatas 10 tahun tidak memiliki perbedaan yang nyata hal ini di karenakan proses penggenangan yang terjadi pada lahan pertanian. Karena menurut Prasetyo et al., (2004) penggenangan pada tanah mineral mengakibatkan nilai $\mathrm{pH}$ 
tanah akan meningkat dan pada tanah basa akan mengakibatkan nilai $\mathrm{pH}$ tanah menurun mendekati netral.

\section{2. pH Potensial Tanah}

Tabel 2 menunjukkan nilai kemasaman potensial pada setiap titik sampel dan rerata, yang ditunjukkan oleh $\mathrm{pH}(\mathrm{KCl})$ tanah pada perlakuan $\mathrm{B}$ dan $\mathrm{C}$ tiap perlakuan tidak berbeda nyata sekaligus juga termasuk dalam harkat masam yakni 4,37 dan 4,65 menurut pengharkatan BPT (2009), sedangkan nilai rerata $\mathrm{pH}(\mathrm{KCl})$ tanah pada perlakuan A terjadi perbedaan nyata dengan perlakuan B dan C sekaligus termasuk dalam harkat masam yakni 5,08 menurut pengharkatan BPT (2009).

Tabel 2. Nilai $\mathrm{pH}(\mathrm{KCl})$ tanah sawah dengan perlakuan perbedaan kurun waktu aplikasi pupuk organik

\begin{tabular}{ccccccccccc}
\hline $\begin{array}{c}\text { Pupuk } \\
\text { organik } \\
\text { selama }\end{array}$ & $\mathbf{1}$ & $\mathbf{2}$ & $\mathbf{3}$ & $\mathbf{4}$ & $\mathbf{5}$ & $\mathbf{6}$ & $\mathbf{7}$ & $\overline{\boldsymbol{x}}$ & $\mathbf{S}$ & $\begin{array}{c}\text { Harkat Menurut } \\
\text { BPT }\end{array}$ \\
\hline A (13 tahun) & 5.79 & 5.2 & 5 & 5.05 & 5.17 & 5.01 & 4.37 & $5.08 \mathrm{a}$ & 0.42 & masam \\
B (7 tahun) & 5.24 & 4.23 & 4.25 & 4.21 & 4.23 & 4.25 & 4.15 & $4.37 \mathrm{~b}$ & 0.39 & masam \\
$\mathrm{C}(3$ tahun) & 4.61 & 4.57 & 4.71 & 4.65 & 4.7 & 4.64 & 4.65 & $4.65 \mathrm{~b}$ & 0.05 & masam \\
\hline
\end{tabular}

Keterangan: $\mathrm{A}=$ Tanah dengan masa penggunaan pupuk organik selama 13 tahun; $\mathrm{B}=$ Tanah dengan masa penggunaan pupuk organik selama 7 tahun; $\mathrm{C}=$ Tanah dengan masa penggunaan pupuk organik selama 3 tahun; $\mathrm{X}=$ Rata-rata nilai sampel; $\mathrm{S}$ = Standar deviasi sampel. Hasil yang diikuti huruf yang sama dalam kolom menunjukkan tidak ada beda nyata pada Uji t-Test SAS pada taraf 5\%

Nilai $\mathrm{pH}(\mathrm{KCl})$ menunjukkan jumlah konsntrasi hidrogen yang terukur dari kompleks pertukaran dan larutan tanah. Berdasarkan hasil yang diperoleh dari penetapan $\mathrm{pH}$ tanah dengan $\mathrm{pH}$ meter, tanah yang diekstrak dengan $\mathrm{KCl} 1 \mathrm{~N}$ memiliki $\mathrm{pH}$ lebih rendah dibandingkan $\mathrm{pH}$ tanah yang diekstrak dengan $\mathrm{H}_{2} \mathrm{O}$. Hal ini dikarenakan konsentrasi ion $\mathrm{H}$ yang diekstrak dengan menggunakan $\mathrm{H}_{2} \mathrm{O}$ adalah konsentrasi ion $\mathrm{H}^{+}$yang hanya berada dalam larutan tanah atau merupakan kemasaman actual. Adapun konsentrasi ion $\mathrm{H}^{+}$yang diekstrak dengan menggunakan $\mathrm{KCl}$ adalah yang berada dalam larutan tanah dan kompleks pertukaran kation tanah, sehingga sebagai kemasaman potensial. Kation $\mathrm{K}^{+}$yang berasal dari $\mathrm{KCl}$ mampu menukar kation $\mathrm{H}^{+}$yang ada di kompleks pertukaran kation keluar kedalam larutan tanah, namun hal tersebut tidak berlaku pada $\mathrm{H}_{2} \mathrm{O}$. Ekstraksi menggunakan $\mathrm{KCl}$ secara umum memberikan konsentrasi ion $\mathrm{H}^{+}$lebih besar, kecuali pada tanah bermuatan terubahkan (variable charge) dengan mineral dominan kaolin dan oksida $\mathrm{Fe}$ dan Al. Berdasarkan hasil penelitian ini yang menujukkan bahwa $\mathrm{pH}(\mathrm{KCl})$ tanah lebih rendah daripada $\mathrm{pH}\left(\mathrm{H}_{2} \mathrm{O}\right)$ memberikan informasi tanah yang diteliti bermuatan tetap.

\section{Daya Hantar Listrik (DHL) Tanah}

Tabel 3 menunjukkan nilai DHL setiap titik sampel dan rerata DHL tanah. Pada perlakuan $\mathrm{B}=7$ tahun dan $\mathrm{C}=3$ tahun tiap perlakuan tidak berbeda nyata sekaligus juga termasuk dalam harkat sangat rendah yakni $64,86 \mu \mathrm{s} / \mathrm{cm}$ dan $72,29 \mu \mathrm{s} / \mathrm{cm}$ menurut 
pengharkatan BPT (2009), sedangkan nilai rerata DHL tanah pada perlakuan $A=13$ tahun terjadi perbedaan nyata dengan perlakuan $\mathrm{B}=7$ tahun dan $\mathrm{C}=3$ tahun namun masih termasuk dalam harkat sangat rendah yakni 137,29 $(\mu \mathrm{s} / \mathrm{cm})$.

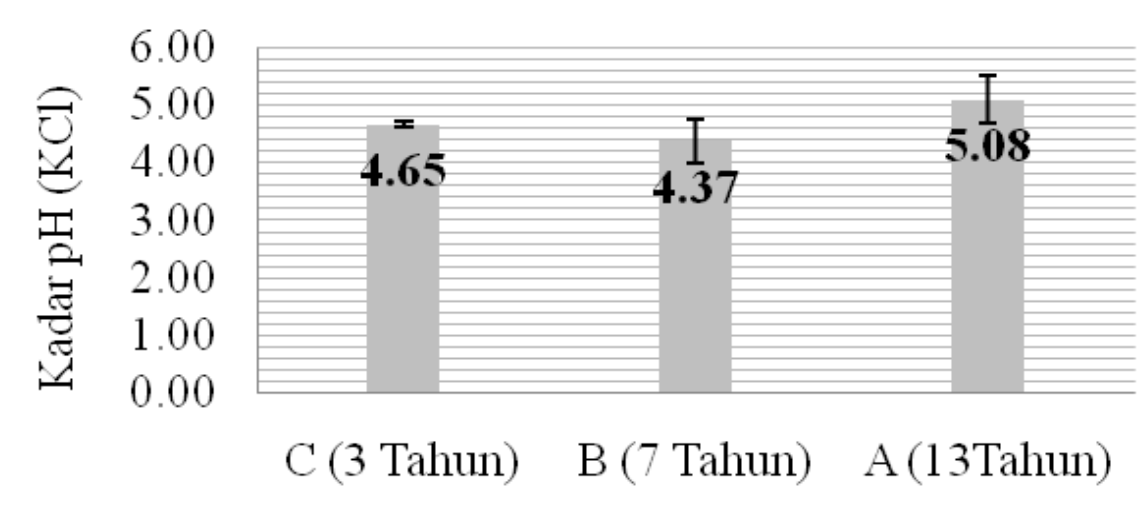

Gambar 2. Rata-rata dan Standar deviasi nilai pH (KCl) tanah dengan perlakuan perbedaan kurun waktu aplikasi pupuk organik

Daya Hantar Listrik (DHL) merupakan kemampuan untuk menghantarkan arus listrik yang dipengaruhi oleh garam-garam terlarut yang dapat terionisasi. DHL dipengaruhi oleh ion, valensi dan konsentrasi. DHL berhubungan dengan pergerakan ion, semakin mudah ion bergerak maka DHL juga semakin besar (Muliawan et al, 2016).

Tabel 3. Nilai DHL tanah sawah dengan perlakuan perbedaan kurun waktu aplikasi pupuk organik

\begin{tabular}{ccccccccccc}
\hline $\begin{array}{c}\text { Pupuk } \\
\text { organik } \\
\text { selama }\end{array}$ & $\mathbf{1}$ & $\mathbf{2}$ & $\mathbf{3}$ & $\mathbf{4}$ & $\mathbf{5}$ & $\mathbf{6}$ & $\mathbf{7}$ & $\overline{\boldsymbol{x}}$ & $\mathbf{S}$ & $\begin{array}{c}\text { Harkat Menurut } \\
\text { BPT }\end{array}$ \\
\hline A (13 tahun) & 90 & 105 & 186 & 135 & 146 & 152 & 147 & $137.29 \mathrm{a}$ & 31.74 & Sangat Rendah \\
$\mathrm{B}(7$ tahun $)$ & 130 & 63 & 49 & 47 & 42 & 60 & 63 & $64.86 \mathrm{~b}$ & 29.91 & Sangat Rendah \\
$\mathrm{C}(3$ tahun $)$ & 62 & 72 & 79 & 67 & 75 & 78 & 73 & $72.29 \mathrm{~b}$ & 6.05 & Sangat Rendah \\
\hline
\end{tabular}

Keterangan: $\mathrm{A}=$ Tanah dengan masa penggunaan pupuk organik selama 13 tahun; $\mathrm{B}=$ Tanah dengan masa penggunaan pupuk organik selama 7 tahun; $\mathrm{C}=$ Tanah dengan masa penggunaan pupuk organik selama 3 tahun; $\mathrm{X}=$ Rata-rata nilai sampel; $\mathrm{S}$ $=$ Standar deviasi sampel. Hasil yang diikuti huruf yang sama dalam kolom menunjukkan tidak ada beda nyata pada Uji t-Test SAS pada taraf $5 \%$

Tanah yang mengandung kadar garam yang sangat tinggi menjadi lebih salin mengakibatkan sel akar tanaman terganggu atau dapat menderita atas tingginya kegaraman tanah. Jika tanaman banyak mengandung berbagai macam konsentrasi ion (garam) yang membuat aliran air alami dari tanah ke akar tanaman ketika keadaan tanah memiliki salin yang cukup tinggi dapat menghambat pergerakan air dari akar tanaman, dan ditarik kembali ke dalam tanah sehingga tanaman tidak dapat mengambil air yang cukup untuk proses pertumbuhan. Jika konsentrasi sisa kadar garam dalam tanah cukup tinggi, tanaman akan layu dan mati terlepas dari jumlah air 
yang diberikan. $\mathrm{Na}^{+}$dalam kondisi dapat dipertukarkan sangat mempengaruhi sifatsifat tanah, terutama jika terdapat dalam kandungan yang berlebihan dalam tanah. Peningkatan konsentrasi garam terlarut dalam tanah akan meningkatkan tekanan osmotik sehingga menghambat penyerapan unsur hara dan penyerapan air sehingga jumlah air yang masuk ke dalam akar berkurang dan mengakibatkan menipisnya jumlah persediaan air dalam tanaman.

Gambar 2 menunjukkan nilai rerata $\mathrm{pH} \mathrm{KCl}$ tanah terendah terdapat pada perlakuan tanah dengan menggunakan pupuk organik $\mathrm{B}=7$ tahun sedangkan nilai rerata $\mathrm{pH}$ tanah tertinggi terdapat pada perlakuan tanah dengan menggunakan pupuk organik $A=13$ tahun. Adanya perbedaan nyata pada perlakuan $A=13$ tahun menunjukkan bahwa pemberian bahan organik dalam jangka waktu panjang dapat mempengaruhi $\mathrm{pH}$ tanah, pemberian pupuk organik dalam jangka waktu panjang akan meningkatkan nilai pH tanah. Menurut Utami dan Handayani (2003) Bahan organik mempunyai daya sangga (buffering capacity) yang besar sehingga apabila tanah cukup mengandung komponen ini, maka $\mathrm{pH}$ tanah relatif stabil. Pengaruh $\mathrm{pH}$ terhadap tanah memilki peranan yang sangat penting terhadap ketersediaan unsurunsur hara, baik hara makro maupun hara mikro. Meningkatnya kelarutan ion-ion $\mathrm{Al}$, dan Fe serta meningkatnya aktivitas jasad- jasad renik tanah sangat dipengaruhi oleh nilai $\mathrm{pH}$ tanah. Pada umumnya unsur hara makro akan lebih tersedia pada $\mathrm{pH}$ agak masam sampai netral, sedangkan unsur hara mikro lebih tersedia pada $\mathrm{pH}$ yanag lebih rendah. Tersedianya unsur hara makro seperti nitrogen, fosfor, kalium dan magnesium pada $\mathrm{pH}$ 6,5. Unsur hara fosfor pada $\mathrm{pH}$ lebih besar dari 8,0 tidak tersedia karena diikat oleh ion $\mathrm{Ca}$. Sebaliknya jika $\mathrm{pH}$ turun menjadi lebih kecil dari 5,0 maka fosfat kembali menjadi tidak tersedia. Hal ini dapat terjadi karena dalam kondisi $\mathrm{pH}$ masam, unsur-unsur seperti $\mathrm{Al}, \mathrm{Fe}$, dan Mn menjadi sangat larut. Fosfat yang semula tersedia dapat diikat oleh lapisan logam-logam tadi sehingga tidak larut dan tidak tersedia untuk tanaman. Beberapa tanaman tertentu dapat kekurangan unsur hara mikro seperti Fe dan Mn. Untuk memperoleh ketersediaan hara yang optimum bagi pertumbuhan tanaman dan kegiatan biologis di dalam tanah, maka $\mathrm{pH}$ tanah harus dipertahankan pada $\mathrm{pH}$ sekitar 6,0 - 7,0. Setiap jenis tanaman berbeda sifat kepekaan dan ketahanannya terhadap reaksi tanah.

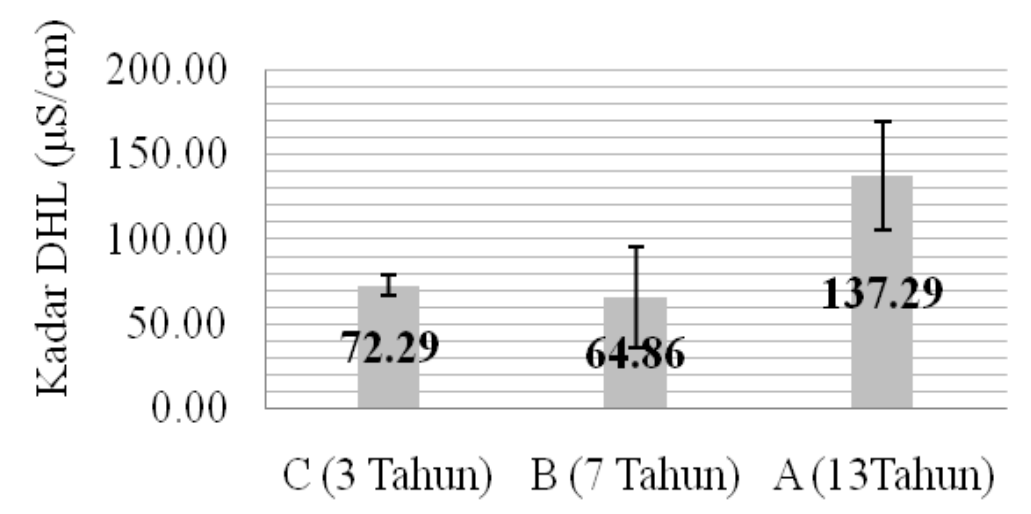

Gambar 3. Rata-rata dan Standar deviasi nilai DHL tanah sawah dengan perlakuan perbedaan kurun waktu aplikasi pupuk organik 
Nilai rerata DHL tanah menunjukkan meningkat dengan semakin lama dilakukan pemupukan organik, dengan nilai tertinggi terdapat pada perlakuan tanah dengan menggunakan pupuk organik $A=13$ tahun yaitu $137.29 \mu \mathrm{s} / \mathrm{cm}$ (Gambar 3). Hal ini menunjukkan bahwa penambahan bahan organik dapat menyebabkan kationkation dapat terikat oleh asam-asam organik menjadi garam, yang bersifat sebagai konduktivitas listrik, namun dalam aras yang rendah, shingga penggunaan pupuk organik di lahan sawah di desa Margoluwih merupakan perbaikan tanah yang sesuai sehingga dapat mempertahan kualitas tanah. Menurut BPT (2009), nilai DHL <1 $\mathrm{mS} / \mathrm{cm}$ masih dalam kriteria sangat rendah dan masih aman untuk pertumbuhan tanaman $\left(1 \mathrm{mS} / \mathrm{cm}=1 \times 10^{3} \mu \mathrm{s} / \mathrm{cm}\right)$. Menurut Muliawana et al., (2016), Tanaman padi termasuk salah satu tanaman yang peka terhadap salinitas tanah sebesar $2 \mathrm{mS} / \mathrm{cm}(2$ $\mathrm{mS} / \mathrm{cm}=2 \mathrm{mS} / \mathrm{cm}=2 \times 10^{3} \mu \mathrm{s} / \mathrm{cm}$ ) dianggap toleran tetapi jika $4-6 \mathrm{mS} / \mathrm{cm}$ tergolong peka terhadap salinitas.

\section{Potensial Redoks (Eh) Tanah}

Reaksi redoks terjadi pada hampir semua tanah. Biasanya, reaksi oksidasi berkaitan dengan kondisi tanah berdrainase baik, sedangkan proses reduksi berkaitan dengan kondisi tanah berdrainase buruk atau apabila terdapat air berlebih. Kondisi redoks tanah mempengaruhi stabilitas senyawa- senyawa besi dan mangan. Potensial redoks mempengaruhi status $\mathrm{N}$ dalam tanah, ketersediaan $\mathrm{P}$ dan $\mathrm{Si}$, kadar $\mathrm{Fe}^{2+}, \mathrm{Mn}^{2+}$, dan $\mathrm{SO}_{4}{ }^{2-}$ secara langsung dan kadar $\mathrm{Ca}^{2+} \mathrm{Mg}^{2+}, \mathrm{Cu}^{+}, \mathrm{Zn}^{2+}$ dan $\mathrm{MoO}_{4}{ }^{2-}$ secara tidak langsung, dekomposisi bahan organik dan $\mathrm{H}_{2} \mathrm{O}$.

Tabel 4. Nilai Eh tanah sawah dengan perlakuan perbedaan kurun waktu aplikasi pupuk organik

\begin{tabular}{cccccccccccc}
\hline $\begin{array}{c}\text { Pupuk } \\
\text { organik } \\
\text { selama }\end{array}$ & $\mathbf{1}$ & $\mathbf{2}$ & $\mathbf{3}$ & $\mathbf{4}$ & $\mathbf{5}$ & $\mathbf{6}$ & $\mathbf{7}$ & $\overline{\boldsymbol{x}}$ & $\mathbf{S}$ & Harkat* $^{*}$ \\
\cline { 2 - 9 } & $\mathrm{A}(13$ tahun) & 40.1 & 51.4 & 48.6 & 37.4 & 55.7 & 60.4 & 48.6 & $48.89 \mathrm{a}$ & 8.11 & tereduksi \\
$\mathrm{B}(7$ tahun $)$ & 84.4 & 80.2 & 63.4 & 100.1 & 19.1 & 14.1 & 57.2 & $59.79 \mathrm{a}$ & 32.69 & tereduksi \\
$\mathrm{C}(3$ tahun $)$ & 60.4 & 60.5 & 66.2 & 62.5 & 88.3 & 52.6 & 85.6 & $68.01 \mathrm{a}$ & 13.58 & tereduksi \\
\hline
\end{tabular}

Keterangan: *Patrick and Mahapatra, 1968, IRRI 1978 dalam Nagur, 2017. A = Tanah dengan masa penggunaan pupuk organik selama 13 tahun; $\mathrm{B}=$ Tanah dengan masa penggunaan pupuk organik selama 7 tahun; $\mathrm{C}=$ Tanah dengan masa penggunaan pupuk organik selama 3 tahun; $X=$ Rata-rata nilai sampel; $S=$ Standar deviasi sampel. Hasil yang diikuti huruf yang sama dalam kolom menunjukkan tidak ada beda nyata pada Uji t-Test SAS pada taraf 5\%

Tabel 4 dan gambar 4 menunjukkan nilai rerata Eh tanah memiliki nilai berturutturut sebesar $\mathrm{A}=48,89 \mathrm{mV}, \mathrm{B}=59,79 \mathrm{mV}$, dan $\mathrm{C}=68.01 \mathrm{mV}$, hal ini juga menunjukkan pada tiap perlakuan tidak berbeda nyata. Nilai rerata tertinggi terdapat pada perlakuan $\mathrm{C}$ dengan nilai $68,01 \mathrm{mV}$ dan terendah terdapat pada perlakuan A yakni $48,89 \mathrm{mV}$. Dari hasil rerata perlakuan Eh tanah di daerah Seyegan termasuk dalam tanah yang tereduksi. Menurut Sondergaard, (2009), tanah yang memiliki potensial $100 \mathrm{mV}$ sampai -100 mV termasuk dalam tanah yang tereduksi, sedangkan tanah yang memiliki potensial redoks di atas $100 \mathrm{mV}$ termasuk tereduksi sedang dan tanah yang memiliki potensial redoks $-100 \mathrm{mV}$ termasuk dalam tereduksi kuat. Kondisi seperti 


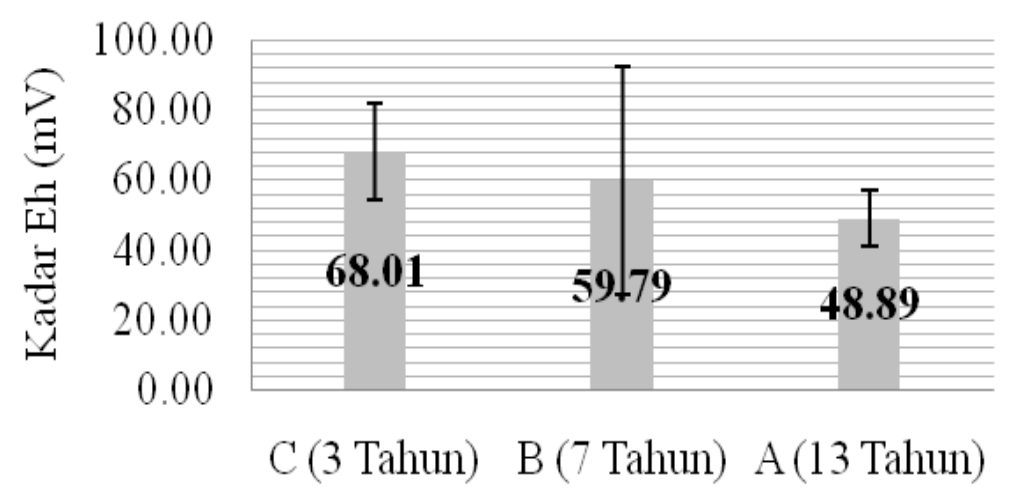

Gambar 4. Rata-rata dan Standar deviasi nilai Eh tanah sawah dengan perlakuan perbedaan kurun waktu aplikasi pupuk organik

ini cukup baik karena dapat mendorong berkurangnya jumlah elektron dalam larutan tanah. Jumlah elektron berbanding lurus dengan potensial redoks sehingga penurunan jumlah elektron secara otomatis akan menurunkan pula nilai Eh. Proses penggenangan akan menyebabkan terjadinya deplesi $\mathrm{O}_{2}$, dan penurunan tersebut akan diikuti oleh penurunan Eh.

Ada beberapa faktor yang mempengaruhi terjadinya reduksi atau oksidasi. Semakin lama suatu tanah tergenang semakin tinggi deplesi $\mathrm{O}_{2}$ dan semakin menurun pula Eh tanah, bahkan bisa sampai pada nilai Eh $-350 \mathrm{mV}$. Menurut Reddy et al., (1984) bila tanah digenangi, persediaan oksigen menurun sampai mencapai nol dalam waktu kurang dari sehari. Laju difusi oksigen udara melalui lapisan air 10 ribu kali lebih lambat dari pada melalui pori yang berisi udara. Mikroba aerob dengan cepat akan menghabiskan udara yang tersisa dan menjadi tidak aktif lagi atau mati. Mikrobia fakultatif anaerob dan obligat aerob kemudian mengambil alih dekomposisi bahan organik tanah dengan menggunakan komponen tanah teroksida (nitrat, $\mathrm{Mn}, \mathrm{Fe}-$ oksida, dan sulfat) atau hasil penguraian bahan organik (fermentasi) sebagai penerima elektron dalam pernapasan (Kyuma, 2004).

Tanah yang tergenang tidak tereduksi secara keseluruhan. Pada lapisan atas setebal 2-20 mm, tetap teroksidasi karena berada dalam keseimbangan dengan oksigen yang terlarut dalam lapisan air. Lapisan di bawahnya merupakan lapisan tereduksi kecuali daerah perakaran yang aktif, karena daerah ini teroksidasi akibat dikeluarkannya senyawa teroksidasi oleh akar yang memperoleh oksigen dari bagian atas (Yoshida, 1981).

\section{B. Perubahan Sifat Kimia Tanah.}

\section{Kadar C-organik tanah}

Kandungan bahan organik (karbon organik) dalam tanah mencerminkan kualitas tanah yang langsung maupun tidak langsung berpengaruh pada kualitas tanah tersebut dan sustainabilitas agronomi karena pengaruhnya pada indikator fisik, kimia dan biologi dari kualitas tanah (Nagur, 2007).

Tabel 5 menunjukkan nilai rerata $\mathrm{C}$-Organik tanah pada perlakuan $\mathrm{B}=7$ tahun dan $\mathrm{C}=3$ tahun tiap perlakuan tidak berbeda nyata sekaligus juga termasuk dalam 
Tabel 5. Efek pupuk organik terhadap kadar C-organik tanah.

\begin{tabular}{|c|c|c|c|c|c|c|c|c|c|c|}
\hline \multirow{2}{*}{$\begin{array}{c}\text { Pupuk } \\
\text { organik } \\
\text { selama }\end{array}$} & \multicolumn{7}{|c|}{ C-organik tanah (\%) sampel } & \multirow{2}{*}{$\bar{x}$} & \multirow{2}{*}{$\mathbf{S}$} & \multirow{2}{*}{$\begin{array}{c}\text { Harkat Menurut } \\
\text { BPT } \\
\end{array}$} \\
\hline & 1 & 2 & 3 & 4 & 5 & 6 & 7 & & & \\
\hline A (13 tahun) & 3,06 & 2,8 & 2,59 & 2,71 & 3,25 & 2,87 & 2,63 & $2,84 \mathrm{a}$ & 0,24 & sedang \\
\hline B (7 tahun) & 1,74 & 1,73 & 1,95 & 1,76 & 1,78 & 1,9 & 2,06 & $1,85 b$ & 0,13 & rendah \\
\hline $\mathrm{C}$ (3 tahun) & 1,86 & 1,92 & 1,74 & 2,25 & 1,81 & 1,68 & 1,8 & $1,87 \mathrm{~b}$ & 0,19 & rendah \\
\hline
\end{tabular}

Keterangan: $\mathrm{A}=$ Tanah dengan masa penggunaan pupuk organik selama 13 tahun; $\mathrm{B}=$ Tanah dengan masa penggunaan pupuk organik selama 7 tahun; $\mathrm{C}=$ Tanah dengan masa penggunaan pupuk organik selama 3 tahun; $X=$ Rata-rata nilai sampel; $S$ = Standar deviasi sampel. Hasil yang diikuti huruf yang sama dalam kolom menunjukkan tidak ada beda nyata pada Uji t-Test SAS pada taraf 5\%

harkat rendah yakni 1,85\% dan 1,87\% menurut pengharkatan BPT (2009), sedangkan nilai rerata $\mathrm{C}$ - Organik tanah pada perlakuan $\mathrm{A}=13$ tahun terjadi perbedaan nyata dengan perlakuan $\mathrm{B}=7$ tahun dan $\mathrm{C}=3$ tahun sekaligus termasuk dalam sedang yakni $2,84 \%$ menurut pengharkatan BPT (2009). Namun nilai rerata tertinggi terdapat pada perlakuan $\mathrm{A}=13$ tahun dengan kadar $2,84 \%$ dan terendah terdapat pada perlakuan $\mathrm{B}=7$ tahun yakni $1,85 \%$.

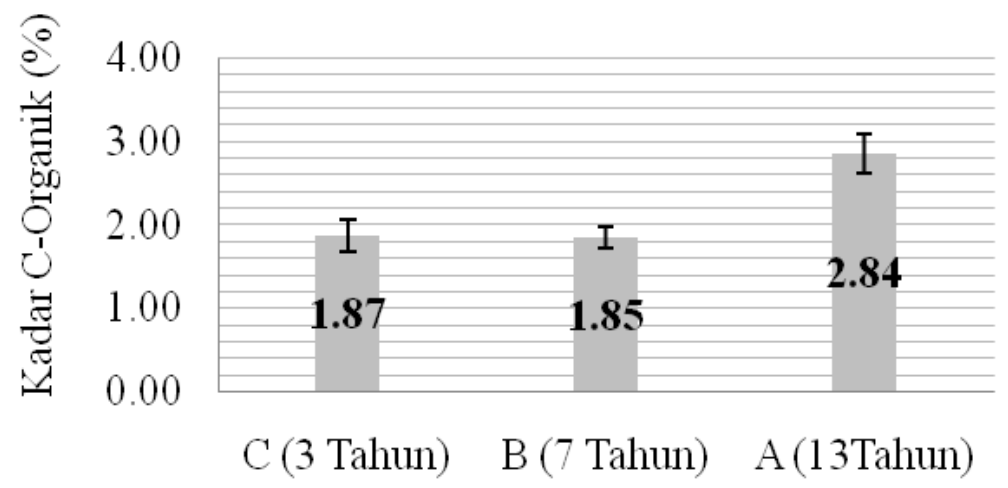

Gambar 5. Rata-rata dan Standar deviasi kadar C-organik tanah sawah dengan perlakuan perbedaan kurun waktu aplikasi pupuk organik

Gambar 5 menunjukkan dari hasil rerata perlakuan, nilai terendah terdapat pada perlakuan $\mathrm{B}=7$ tahun, hal ini terjadi di karenakan proses peningkatan dekomposisi bahan organik akibat pengolahan tanah dan hilang akibat terangkut erosi, karena peningkatan dekomposisi menghasilkan $\mathrm{CO}_{2}$ melalui proses respirasi mikroorganisme. Bellamy et al., (2005) mengatakan bahwa intensitas pengolahan lahan dan perubahan pengolahan lahan merupakan dua faktor yang paling bertanggung jawab terhadap hilangnya kadar karbon tanah di lahan pertanian inggris. Terjadinya peningkatan kadar C-Organik pada perlakuan $\mathrm{A}=13$ tahun menunjukkan bahwa perlakuan pupuk organik dalam jangka waktu lebih dari 10 tahun berpengaruh pada C-Organik tanah. Budidaya organik nyata meningkatkan kandungan karbon tanah. Tingginya karbon tanah ini akan mempengaruhi sifat tanah menjadi lebih baik, baik secara fisik, kimia dan biologi. Karbon merupakan sumber makanan 
mikroorganisme tanah, sehingga keberadaan unsur ini dalam tanah akan memacu kegiatan mikroorganisme sehingga meningkatkan proses dekomposisi tanah dan juga reaksi-reaksi yang memerlukan bantuan mikroorganisme, misalnya pelarutan $\mathrm{P}$, fiksasi N dan sebagainya (Utami dan Handayani, 2003).

Dari hasil rerata C-Organik pengharkatan tanah masuk ke dalam harkat sedang dan rendahmenurut BPT (2009) hal ini menunjukkan bahwa tanah di daerah Seyegan belum ideal untuk produktifitas tanah. Menurut Neneng et al., (2014) tanah memiliki produktivitas yang baik apabila kadar bahan organik berkisar antara 8\% sampai $16 \%$ atau kadar karbon organik 4,56\% sampai 9,12\%. Penambahan bahan organik tanah atau karbon organik tanah merupakan salah satu usaha untuk memperbaiki tanah. Bahan organik tanah erat kaitannya dengan kondisi ideal tanah baik secara fisik, kimia, dan biologi yang selanjutnya menentukan produktivitas suatu tanah (Wander et al., 1994 dan Neneng et al., 2014).

\section{P-tersedia dalam tanah.}

Tabel 6 menunjukkan nilai rerata P-tersedia tanah yang memiliki nilai berturutturut sebesar $A=49,29(\mathrm{ppm}), \mathrm{B}=59,86(\mathrm{ppm})$, dan $\mathrm{C}=70.43$ (ppm) hal ini juga menunjukkan pada tiap perlakuan tidak berbeda nyata sekaligus juga termasuk dalam harkat sangat tinggi menurut pengharkatan BPT (2009), namun nilai rerata tertinggi terdapat pada perlakuan $\mathrm{C}=3$ tahun dengan kadar 70,43 ppm dan terendah terdapat pada perlakuan $\mathrm{A}=13$ tahun yakni 49,29 ppm.

Tabel 6. Kadar P-tersedia tanah sawah dengan perlakuan perbedaan kurun waktu aplikasi pupuk organik

\begin{tabular}{|c|c|c|c|c|c|c|c|c|c|c|}
\hline \multirow{2}{*}{$\begin{array}{l}\text { Pupuk organik } \\
\text { selama }\end{array}$} & \multicolumn{7}{|c|}{ P-tersedia tanah (ppm) sampel } & \multirow{2}{*}{ Rerata } & \multirow{2}{*}{$\mathbf{S}$} & \multirow{2}{*}{$\begin{array}{c}\text { Harkat Menurut } \\
\text { BPT }\end{array}$} \\
\hline & 1 & 2 & 3 & 4 & 5 & 6 & 7 & & & \\
\hline A (13 tahun) & 48 & 30 & 38 & 43 & 97 & 47 & 42 & $49.29 \mathrm{a}$ & 21.89 & sangat tinggi \\
\hline B (7 tahun) & 140 & 104 & 96 & 25 & 25 & 16 & 13 & $59.86 \mathrm{a}$ & 52.00 & sangat tinggi \\
\hline $\mathrm{C}$ (3 tahun) & 68 & 65 & 69 & 73 & 73 & 77 & 68 & $70.43 \mathrm{a}$ & 4.08 & sangat tinggi \\
\hline
\end{tabular}

Keterangan: $\mathrm{A}=$ Tanah dengan masa penggunaan pupuk organik selama 13 tahun; $\mathrm{B}=$ Tanah dengan masa penggunaan pupuk organik selama 7 tahun; $\mathrm{C}=$ Tanah dengan masa penggunaan pupuk organik selama 3 tahun; $X=$ Rata-rata nilai sampel; $S$ = Standar deviasi sampel. Hasil yang diikuti huruf yang sama dalam kolom menunjukkan tidak ada beda nyata pada Uji t-Test SAS pada taraf 5\%

Dari hasil uji T-test pada tiap rerata perlakuan terdapat penurunan hasil $\mathrm{P}$ tersedia tanah pada perlakuan $\mathrm{A}=13$ tahun dan $\mathrm{B}=7$ tahun (gambar 6). Hal ini di karenakan pada masa waktu yang lama P-tersedia akan terfiksasi dan tencuci sehingga masuk ke dalam tanah sehingga menjadi tidak tersedia bagi tanaman. Menurut Novriani (2010) makin lama antara P-tersedia dan tanah bersentuhan, semakin banyak $\mathrm{P}$ terfiksasi. Hal ini juga berhubungan dengan terbentuknya Al-P dan Fe-P pada tanah yang mempunyai daya fiksasi tinggi maka masa penggunaan P-tersedia akan lebih pedek. Sehubungan dengan itu maka cara dan waktu pemberian pupuk fosfat harus dipertimbangkan. Sedangkan pada perlakuan $\mathrm{C}=3$ tahun, peningkatan P-tersedia di akibatkan oleh pemberian bahan organik dalam tanah, karena P-tersedia diikat dalam 


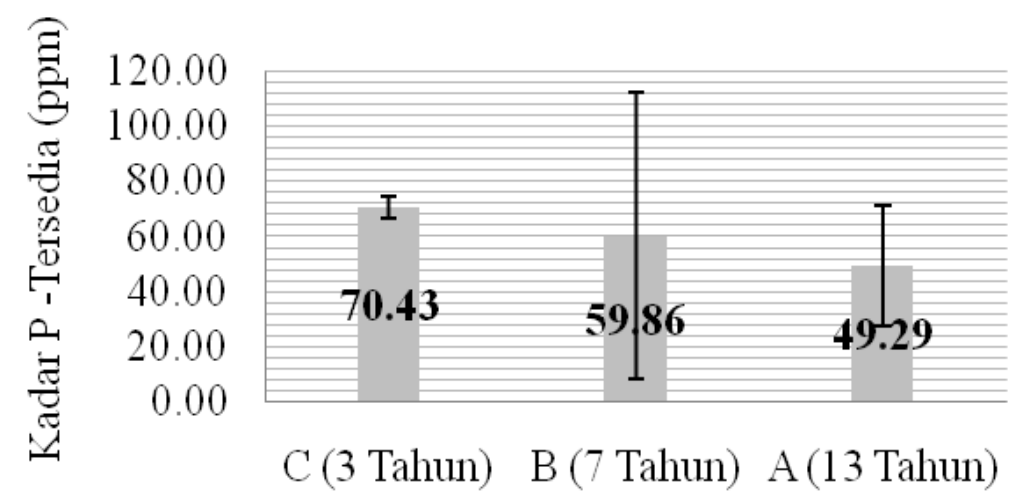

Gambar 6. Rata-rata dan Standar deviasi kadar P-tersedia tanah dengan perlakuan perbedaan kurun waktu aplikasi pupuk organik

bentuk organik atau dalam tubuh mikroorganisme, dan ion-ion yang bermuatan positif masih berada di sekitaran akar tanaman, sehingga terhindar dari pencucian. Jika dilihat hasil rerata seluruh sampel tanah, harkat untuk P-tersedia termasuk ke dalam harkat sangat tinggi menurut pengharkatan BPT (2009), hal ini di karenakan $\mathrm{pH}$ tanah yang rendah, karena $\mathrm{pH}$ tanah yang masam menentukan kelarutan fosfat. Fosfat alam lebih mudah larut pada tanah yang memiliki $\mathrm{pH}$ rendah (masam), sebaliknya pada tanah dengan $\mathrm{pH}$ tinggi sulit kelarutannya. Hal ini sesuai dengan pendapat Nagur (2017) bahwa $\mathrm{pH}$ tanah merupakan salah satu faktor yang mempengaruhi tersedia nya unsur P-tersedia dalam tanah, $\mathrm{pH}$ yang rendah menyebabkan ketersediaan unsur Ptersedia meningkat.

Dekomposisi bahan organik menghasilkan asam-asam organik seperti asam humat dan fulfat yang bersifat polielektrolit (Polielektrolit adalah polimer yang memiliki gugus elektrolit). Kedua asam ini memegang peranan penting dalam pengikatan $\mathrm{Al}$ dan $\mathrm{Fe}$ sehingga $\mathrm{P}$ menjadi tersedia. Keefektifan pengikatan tersebut dipengaruhi oleh struktur bahan organik yang ditambahkan dan $\mathrm{pH}$ medium (Utami, dan Handayani, 2003). Ditambahkan bahwa adanya senyawa organik yang cukup memungkinkan terjadinya khelat yaitu senyawa organik yang berikatan dengan kation logam ( Fe, Mn, Al). Terbentuknya khelat logam akan mengurangi pengikatan Ptersedia oleh oksida maupun lempung silikat sehingga $\mathrm{P}$ menjadi lebih tersedia.

Peningkatan ketersediaan P-tersedia juga dimungkinkan karena pupuk organik yang diberikan mengandung konsorsium mikroba pelarut P-tersedia yaitu Pseudomonas sp., Bacillus sp., dan Aspergillus nigger. Pada dasarnya fosfor relatif tidak mudah tercuci, dalam aktivitasnya, mikroba pelarut P-tersedia akan menghasilkan asam-asam organik diantaranya adalah asam sitrat, glutamat, suksinat, laktat, oksalat, glioksalat, malat, fumarat, tartarat dan $\alpha$-ketobutirat. Meningkatnya asam-asam organik tersebut biasanya diikuti dengan penurunan $\mathrm{pH}$, sehingga mengakibatkan terjadinya pelarutan $\mathrm{P}$ - tersedia yang terikat oleh Ca. Asam organik juga mampu meningkatkan ketersediaan P-tersedia dengan cara menutupi daerah absorpsi P-tersedia pada partikel tanah atau dengan cara membentuk kompleks dengan kation pada permukaan mineral tanah (Saraswati et al.,2007). 


\section{K-tersedia tanah}

Tabel 7 menunjukkan nilai rerata K-tersedia tanah terjadi perbedaan yang nyata pada perlakuan A dan B sekaligus juga termasuk dalam harkat sangat tinggi yakni 101,29 (ppm) dan 58,00 (ppm) menurut pengharkatan BPT (2009), namun nilai rerata tertinggi terdapat pada perlakuan A dengan kadar 101,29 (ppm) dan terendah terdapat pada perlakuan B yakni 58,00 (ppm). Dari hasil di atas (Gambar 7) dapat diketahui bahwa nilai rerata terendah terdapat pada perlakuan $B=7$ tahun, hal ini dimungkinkan pada setiap lahan memiliki perlakuan pupuk organik yang berbeda takaran dengan lahan yang memiliki perlakuan $\mathrm{A}=13$ tahun dan $\mathrm{C}=3$ tahun. Selain itu juga dimungkinkan karena unsur hara $\mathrm{K}$ termasuk unsur hara mobil sehingga mudah berpindah terbawa air hujan dan temperatur dapat mempercepat pelepasan dan pelapukan mineral dalam pencucian kalium (Soegianto, 2017).

Jika dilihat hasil rerata seluruh sampel tanah, harkat untuk $\mathrm{K}$ termasuk ke dalam harkat sangat tinggi menurut pengharkatan BPT (2009). Hal ini menunjukkan bahwa pemberian pupuk organik memberikan dampak yang baik pada $\mathrm{K}$ tanah, pada beberapa pupuk kandang terutama pupuk kandang sapi dan kambing memiliki kandungan kalium yang cukup tinggi yang dapat dimanfaatkan di lahan pertanian, selain itu K yang terdapat dalam larutan tanah berada dalam bentuk keseimbangan dengan $\mathrm{K}$ yang diadsorpsi liat.

Tabel 7. Kadar K-tersedia tanah sawah dengan perlakuan perbedaan kurun waktu aplikasi pupuk organik

\begin{tabular}{|c|c|c|c|c|c|c|c|c|c|c|}
\hline \multirow{2}{*}{$\begin{array}{c}\text { Pupuk } \\
\text { organik } \\
\text { selama }\end{array}$} & \multicolumn{7}{|c|}{ K-tersedia tanah (ppm) Sampel } & & \multirow{2}{*}{$\mathbf{S}$} & \multirow{2}{*}{$\begin{array}{c}\text { Harkat Menurut } \\
\text { BPT }\end{array}$} \\
\hline & 1 & 2 & 3 & 4 & 5 & 6 & 7 & & & \\
\hline$\overline{\mathrm{A}(13 \text { tahun })}$ & 112 & 84 & 81 & 106 & 111 & 103 & 112 & $101.29 \mathrm{a}$ & 13.29 & sangat tinggi \\
\hline B (7 tahun) & 118 & 106 & 90 & 21 & 43 & 18 & 10 & $58.00 \mathrm{~b}$ & 45.51 & sangat tinggi \\
\hline $\mathrm{C}$ (3 tahun) & 69 & 61 & 60 & 108 & 113 & 80 & 85 & $82.29 \mathrm{ab}$ & 21.38 & sangat tinggi \\
\hline
\end{tabular}

Keterangan: $\mathrm{A}=$ Tanah dengan masa penggunaan pupuk organik selama 13 tahun; $\mathrm{B}=$ Tanah dengan masa penggunaan pupuk organik selama 7 tahun; $\mathrm{C}=$ Tanah dengan masa penggunaan pupuk organik selama 3 tahun; $\mathrm{X}=$ Rata-rata nilai sampel; $\mathrm{S}$ = Standar deviasi sampel. Hasil yang diikuti huruf yang sama dalam kolom menunjukkan tidak ada beda nyata pada Uji t-Test SAS pada taraf 5\%

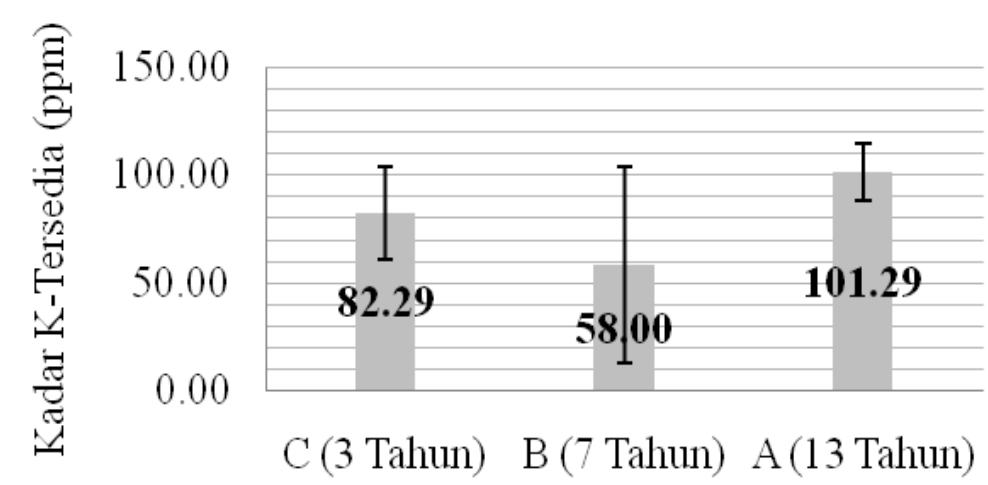

Gambar 7. Rata-rata dan Standar deviasi kadar K-tersedia tanah dengan perlakuan perbedaan kurun waktu aplikasi pupuk organik 
Penurunan Eh akibat penggenangan akan menghasilkan $\mathrm{Fe}^{2+}$ dan $\mathrm{Mn}^{2+}$ yang dalam jumlah besar dapat menggantikan $\mathrm{K}$ yang diadsorpsi sehingga $\mathrm{K}$ dilepaskan ke dalam larutan dan tersedia bagi tanaman. Oleh sebab itu penggenangan dapat meningkatkan ketersediaan K tanah. Yoshida (1981) dan Prasetyo et al. (2004) mengemukakan bahwa respon padi sawah terhadap pemupukan $\mathrm{K}$ umumnya rendah karena kebutuhan $\mathrm{K}$ dapat dicukupi dari cadangan mineral $\mathrm{K}$ yang berada dalam keseimbangan dengan $\mathrm{K}$ dalam larutan tanah dan air irigasi serta dekomposisi bahan organik. Pada tanah sawah yang drainasenya buruk atau potensial redoksnya sangat rendah, dapat terjadi kekahatan K. Hal ini karena daya oksidasi akar sekitar rizosfer sangat rendah serta adanya akumulasi asam-asam organik dalam larutan tanah yang dapat menghambat serapan K oleh akar (Prasetyo et al., 2004). Tingginya kandungan kalium sangatlah baik untuk pertumbuhan tanaman, karena berpengaruh terhadap proses metabolisme, fisiologi dan nutrisi serta dibutuhkan dalam jumlah yang banyak untuk mencapai tingkat produksi yang tinggi. Tingginya kandungan $\mathrm{K}$ dibandingkan unsur hara yang lain pada lahan organik atau pun lahan anorganik dikarenakan $\mathrm{K}$ dapat tersedia dalam kondisi Eh rendah. Selain itu kelembaban tanah dan suhu optimal menyebabkan kalium yang terjerap pada mineral tanah terlepas sehingga menambah ketersediaan hara $\mathrm{K}$ untuk diserap oleh tanaman.

\section{N-Total Tanah}

Tabel 8. Kadar N-total tanah sawah dengan perlakuan perbedaan kurun waktu aplikasi pupuk organik

\begin{tabular}{|c|c|c|c|c|c|c|c|c|c|c|}
\hline \multirow{2}{*}{$\begin{array}{c}\text { Pupuk } \\
\text { organik } \\
\text { selama }\end{array}$} & \multicolumn{7}{|c|}{ kadar N-total tanah (\%) sampel } & \multirow{2}{*}{$\bar{x}$} & \multirow{2}{*}{$\mathbf{S}$} & \multirow{2}{*}{ Harkat BPT } \\
\hline & 1 & 2 & 3 & 4 & 5 & 6 & 7 & & & \\
\hline A (13 tahun) & 0.21 & 0.23 & -0.01 & 0.22 & 0.27 & 0.23 & 0.21 & $0.19 \mathrm{a}$ & 0.09 & rendah \\
\hline B (7 tahun) & 0.17 & 0.16 & 0.17 & 0.27 & 0.16 & 0.15 & 0.19 & $0.18 \mathrm{a}$ & 0.04 & rendah \\
\hline $\mathrm{C}$ (3 tahun) & 0.15 & 0.18 & 0.16 & 0.19 & 0.17 & 0.17 & 0.16 & $0.17 \mathrm{a}$ & 0.01 & rendah \\
\hline
\end{tabular}

Keterangan: $\mathrm{A}=$ Tanah dengan masa penggunaan pupuk organik selama 13 tahun; $\mathrm{B}=$ Tanah dengan masa penggunaan pupuk organik selama 7 tahun; $\mathrm{C}=$ Tanah dengan masa penggunaan pupuk organik selama 3 tahun; $\mathrm{X}=$ Rata-rata nilai sampel; $\mathrm{S}$ = Standar deviasi sampel. Hasil yang diikuti huruf yang sama dalam kolom menunjukkan tidak ada beda nyata pada Uji t-Test SAS pada taraf 5\%

Tabel 8 menunjukkan nilai rerata $\mathrm{N}$-total tanah memiliki nilai berturut- turut sebesar $\mathrm{A}=0,19 \%, \mathrm{~B}=0,18 \%$, dan $\mathrm{C}=0,17 \%$ hal ini juga menunjukkan pada tiap perlakuan tidak berbeda nyata sekaligus juga termasuk dalam harkat rendah menurut pengharkatan BPT (2009). Namun nilai rerata tertinggi terdapat pada perlakuan $A=13$ tahun dengan kadar $0.19 \%$ dan terendah terdapat pada perlakuan $\mathrm{C}=3$ tahun yakni $0,17 \%$.

Gambar 8 menunjukkan adanya peningkatan nilai rerata tiap perlakuan $\mathrm{N}$-total tanah. Hal ini menunjukkan bahwa perlakuan pupuk organik (terutama kotoran unggas dan azolla) dengan kurun waktu yang semakin lama akan mampu meningkatkan kandungan $\mathrm{N}$-total tanah meskipun belum maksimal dan dalam kondisi rendah, rendahnya $\mathrm{N}$ - total tanah ini dikarenakan $\mathrm{N}$-total tanah mengalami proses denitrifikasi. Denitrifikasi yaitu proses berubahnya nitrat dan nitrit menjadi gas $\mathrm{N}_{2}$ dan $\mathrm{N}_{2} \mathrm{O}$ yang akan kembali ke atmosfir (Nagur, 2017). Rendahnya kadar $\mathrm{N}$ total 


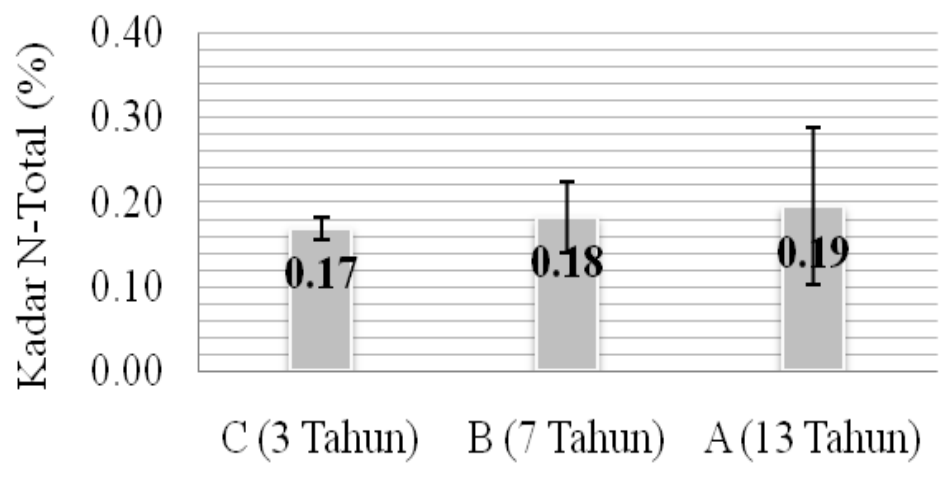

Gambar 8. Rata-rata dan Standar deviasi kadar N-Total tanah dengan perlakuan perbedaan kurun waktu aplikasi pupuk organik

dalam tanah selain dari faktor diatas juga dipengaruhi pencucian (hujan) yang terjadi dalam tanah tersebut. Hal tersebut sesuai dengan pernyataan Triyono et al., (2013) yang menyatakan bahwa pada keadaan yang tergenang unsur hara $\mathrm{N}$ dapat mengalami pencucian.

Sebagian besar $\mathrm{N}$ tanah berupa $\mathrm{N}$ organik baik yang terdapat dalam bahan organik tanah maupun fiksasi $\mathrm{N}$ oleh mikroba tanah dan hanya sebagian kecil (2-5\%) berupa $\mathrm{N}$ anorganik yaitu $\mathrm{NH}^{4+}$ dan $\mathrm{NO}^{3-}$ serta sedikit $\mathrm{NO}^{2-}$. Pada tanah tergenang $\mathrm{N}$ merupakan hara yang tidak stabil karena adanya proses mineralisasi bahan organik (amonifikasi nitrifikasi dan denitrifikasi) oleh mikroba tanah tertentu. Pada lapisan atas dimana oksigen masih cukup, proses mineralisasi dapat menghasilkan $\mathrm{NO}^{3-}$. Mineralisasi bahan organik:

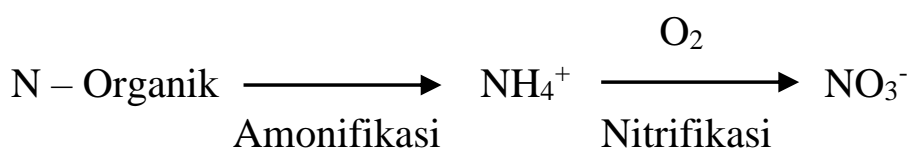

Sedangkan pada lapisan di bawahnya yang sifatnya reduktif (tanpa oksigen) maka asimilasi akan berhenti sampai amonifikasi yaitu terbentuknya $\mathrm{NH}^{4+}$. Nitrat $\left(\mathrm{NO}^{3+}\right)$ yang terbentuk di lapisan atas (lapisan oksidasi) sebagian akan berdifusi ke lapisan reduksi dan selanjutnya akan terjadi proses denitrifikasi yaitu terbentuknya gas $\mathrm{N}_{2} \mathrm{O}$ atau $\mathrm{N}_{2}$ yang hilang ke udara. Penelitian Prasetyo et al. (2004) menunjukkan bahwa kehilangan $\mathrm{N}$ melalui kedua proses tersebut dapat mencapai $70 \%$. Oleh karena itu pemupukan $\mathrm{N}$ harus diberikan ke dalam lapisan reduksi dengan beberapa kali pemberian untuk mengurangi kehilangan $\mathrm{N}$ sehingga efisiensinya meningkat.

Dari hasil rerata setiap perlakuan termasuk ke dalam harkat rendah menurut pengharkatan BPT (2009), hal ini menunjukkan pemberian pupuk kandang dan azolla pada lahan pertanian organik di desa Margoluwih belum mampu memberikan hasil yang optimal bagi tersedia nya nitrogen tanah, dari hasil survei di lapangan para petani menggunakan azolla dan kotoran unggas (bebek) untuk meningkatkan $\mathrm{N}$ tanah. Kesetimbangan unsur hara tentang pengembalian $80 \%$ sisa-sisa tanaman dapat memperkaya cadangan unsur hara, sehingga mengurangi kebutuhan hara yang harus ditambahkan. Perlakuan ini jika dilakukan secara terus menerus akan mengurangi 
kebutuhan hara sehingga akan dicapai kondisi hara yang cukup untuk pertumbuhan dan produksi tanaman tinggi tanpa ada masukan pupuk anorganik.

\section{Pengaruh Pupuk Organik Terhadap N-total, P- dan K- tersedia Tanah.}

Gambar 9. Menunjukkan bahwa perlakuan pemberian pupuk organik $\mathrm{C}=3$ tahun memiliki nilai berturut-turut pada kadar K-tersedia sebesar 82.29 ppm, kadar Ptersedia sebesar $70.49 \mathrm{ppm}$, kadar $\mathrm{N}$-total $0.17 \%$. Perlakuan $\mathrm{B}=7$ tahun memiliki nilai berturut-turut pada kadar N-total $0.18 \%$, kadar P-tersedia sebesar 59.86 ppm, kadar K-tersedia sebesar 58.00 ppm. Perlakuan $\mathrm{A}=13$ tahun memiliki nilai berturutturut pada kadar N-total $0.19 \%$, kadar K-tersedia sebesar 101.29 ppm, kadar Ptersedia sebesar $49.29 \mathrm{ppm}$.

Berdasarkan Gambar 9 dapat juga diketahui bahwa kadar K-tersedia tanah sawah mengalami penurunan pada perlakuan pemupukan selama 3 tahun, yaitu 82.29 ppm menjadi 58.00 ppm pada perlakuan 7 tahun. Setelah itu kembali mengalami peningkatan cukup tinggi pada perlakuan 13 tahun, yaitu 101.29 ppm. Kadar Ptersedia tanah mengalami penurunan yang cukup tinggi pada perlakuan 3 tahun 70.49 ppm, 7 tahun 59.86 ppm, dan 13 tahun 49.29 ppm.

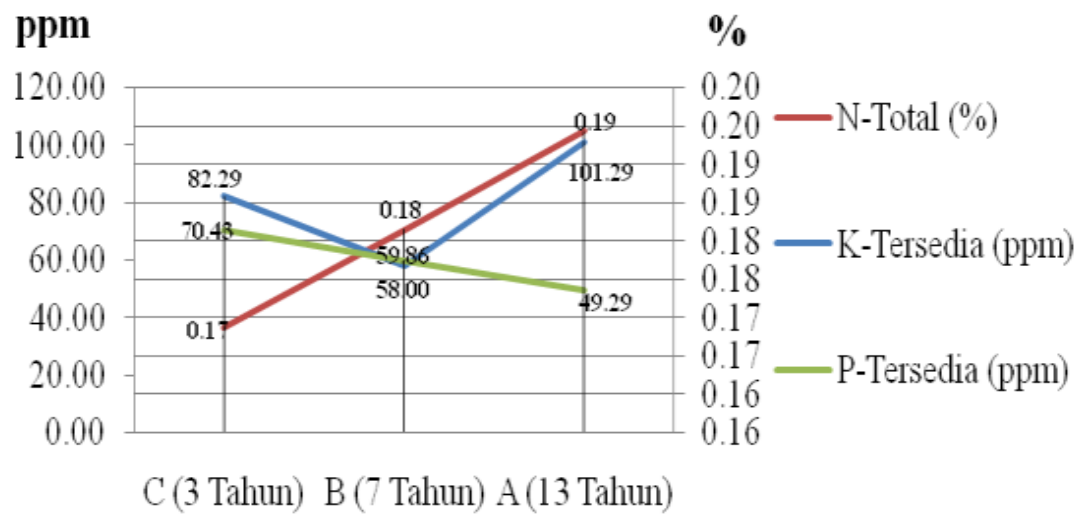

Gambar 9. Hasil efek pupuk organik terhadap kadar N-total, P-tersedia, dan K-tersedia tanah dengan perlakuan perbedaan kurun waktu aplikasi pupuk organik

Sedangkan pada kadar $\mathrm{N}$-total tanah mengalami peningkatan yang cukup tinggi pada perlakuan 3 tahun $0.17 \%, 7$ tahun $0.18 \%$. dan 13 tahun $0.19 \%$. Jika di lihat dari hasil kumulatif kadar NPK tanah sawah maka dapat kita ketahui bahwa penggunaan pupuk organik 3 tahun sampai 13 tahun dapat meningkatkan K-tersedia dan N-total tanah. Akan tetapi menurunkan kadar P-tersedia tanah sawah.

\section{KESIMPULAN}

1. Berdasarkan hasil penelitian, dapat disimpulkan bahwa perlakuan pupuk organik $\mathrm{A}=13$ tahun pada tanah sawah dapat meningkatkan $\mathrm{pH}(\mathrm{KCl})$ yakni dari 4,37 (7 tahun) menjadi 5,08 (13 tahun), DHL dari 64,86 $\mu \mathrm{S} / \mathrm{cm}$ (7 tahun) menjadi 137,29 $\mu \mathrm{S} / \mathrm{cm}(13$ tahun), C-Organik yakni dari 1,85\% (7 tahun) menjadi 2,84\% (13 tahun), K-Tersedia 
yakni dari 58,00 ppm (7 tahun) menjadi 101,29 ppm (13 tahun), dan N-Total yakni dari $0,17 \%$ (3 tahun) menjadi $0,19 \%$ (13 tahun). Tanah sawah yang diteliti itu mengalami penurunan P-Tersedia yakni dari 70,43 ppm (3 tahun) menjadi 49,29 ppm (13 tahun) dan Eh yakni dari 68,01 mV (3 tahun) menjadi 48,89 mV (13 tahun).

2. Perlakuan pupuk organik pada tanah Latosol di Desa Margoluwih, Sayegan, Sleman memiliki nilai rerata tertinggi pada perlakuan 13 tahun dengan nilai rerata tertinggi pada C-Organik, K Tersedia, dan N Total tanah.

\section{DAFTAR PUSTAKA}

Annisa, W. 2014. Peran Bahan Organik dan Tata Air Mikro Terhadap Kelarutan Besi, Emisi CH4, Emisi $\mathrm{CO}_{2}$ dan Produktivitas Padi di Lahan Sulfat Masam. Disertasi Pascasarjana Universitas Gadjah Mada. Yogyakarta. Indonesia.

Bellamy, P. H., Loveland, P. J., Bradley, R. I., Lark, R. M., dan Kirk, G. J. 2005. Carbon losses from all soils across England and Wales 1978-2003. Nature, 437(7056), 245-248.

BPT (Balai Penelitian Tanah). 2005. Petunjuk Teknis Analisis Kimia Tanah, Tanaman, Air, dan Pupuk. Balai Penelitian Tanah, Badan Penelitian dan Pengembangan Pertanian, Departemen Pertanian. Bogor.

BPT (Balai Penelitian Tanah). 2009. Petunjuk Teknis Analisis Kimia Tanah, Tanaman, Air, dan Pupuk. Balai Penelitian Tanah, Badan Penelitian dan Pengembangan Pertanian, Departemen Pertanian. Bogor. Edisi ke-2. Hal 7-207. Bogor.

Gong, W., Yan, X. Y., Wang, J. Y., Hu, T. X., dan Gong, Y. B. 2009. Long-term manuring and fertilization effects on soil organic carbon pools under a wheat-maize cropping system in North China Plain. Plant and Soil, 314(1-2), 67-76.

Kyuma K. 2004. Paddy soil science. Kyoto, Japan: Kyoto University Press.

Muddarisna, N. dan Sugeng, P. 2009.Implementasi Pemeliharaan Lahan Budidaya Ubikayu Melalui Perbaikan dan Monitoring Kualitas Tanah. Jurnal Buana Sains. 9 (1); 49-56.

Muliawan, N. R. E., Sampurno, J., dan Jumarang, M. I. 2016. Identifikasi nilai salinitas pada lahan pertanian di daerah Jungkat berdasarkan metode daya hantar listrik (DHL). Prisma Fisika, 4(2).

Muliawana, E, N. Sampurna, R, J. dan M, Ishak. 2016. Identifikasi Nilai Salinitas Pada Lahan Pertanian di Daerah Jungkat Berdasarkan Metode Daya Hantar Listrik (DHL). Jurnal Prisma Fisika. 4 (2); 69-72.

Nagur, Y, K. 2017. Kajian Hubungan Bahan Organik Tanah Terhadap Produktivitas Lahan Tanaman Padi di Desa Kebonagung. Skripsi Jurusan Agroteknologi Fakultas Pertanian Universitas Pembangunan Nasional "Veteran" Yogyakarta.

Neneng, L, Nurida, dan Jubaedah. 2014. Teknologi Peningkatan Cadangan Karbon Lahan Kering dan Potensinya pada Skala Nasional. Dalam: Konservasi Tanah Menghadapi Perubahan Iklim. Penerbit Badan Penelitian dan Pengembangan Pertanian, Kementrian Pertanian. Bogor.

Novriani. 2010. Alternative Pengelolaan Unsur Hara $\mathrm{P}_{2} \mathrm{O}_{5}$ (Fosfor) pada Budidaya Jagung. Jurnal Agronobis. 1 (2). Hal 42-49.

Prasetyo, B, H. J, S, Adiningsih. K, Subagyono. dan R, D, M, Simanungkalit. 2004. Mineralogi, Kimia, Fisika, Dan Biologi Tanah Sawah. Dalam: Tanah Sawah dan Teknologi Pengolahannya. Pusat Penelitian dan Pengembangan Tanah 
Agroklimat. Badan Penelitian dan Pengembangan Pertanian, Bogor.

Reddy, K. R., Patrick, W. H., dan Broadbent, F. E. 1984. Nitrogen transformations and loss in flooded soils and sediments. Critical Reviews in Environmental Science and Technology, 13(4), 273-309.

Roidah, I, S. 2013. Manfaat penggunaan pupuk organik untuk kesuburan tanah. Jurnal Universitas Tulungagung Bonorowo. 1 (1); 30-42.

Saraswati, R. Prihatini, T. dan Hastuti, R, D. 2004. Teknologi pupuk mikroba untuk meningkatkan efisiensi pemupukan dan keberlanjutan sistem produksi padi sawah. Dalam: Tanah Sawah dan Teknologi Pengolahannya. Penerbit Pusat Penelitian dan Pengembangan Tanah Agroklimat. Badan Penelitian Dan Pengembangan Pertanian, Bogor.

Siregar, A. F., dan Hartatik, W. 2010. Aplikasi pupuk organik dalam meningkatkan efisiensi pupuk anorganik pada lahan sawah. In Prosiding Seminar Nasional Sumberdaya Lahan Pertanian. Buku II (pp. 23-38).

Soegianto, H. 2017. Pengaruh Blotong dan Abu Ketel Terhadap Serapan Hara NPK dan Pertumbuhan Tanaman Tebu (Saccharum Officinarum L.) di Ultisol Tulang Bawang. Tesis Program Pascasarjana Fakultas Pertanian Universitas Gadjah Mada. Universitas Gadjah Mada. Yogyakarta.

Søndergaard, M. 2009. Redox potential. In Encyclopedia of Inland Waters (pp. 852-859). Pergamon Press.

Suriadarma, A. 2011. Dampak Beberapa Parameter Faktor Fisik Kimia Terhadap Kualitas Lingkungan Perairan Wilayah Pesisir Karawang-Jawa Barat. Riset Geologi dan Pertambangan, 21(1), 19-33.

Utami, S, N, H. dan S, Handayani. 2003. Sifat Kimia Entisol Pada Sistem Pertanian Organik. Jurnal Ilmu Pertanian. 10 (2); 63-69

Wander, M. M., Traina, S. J., Stinner, B. R., dan Peters, S. E. 1994. Organic and conventional management effects on biologically active soil organic matter pools. Soil Science Society of America Journal, 58(4), 1130-1139.

Yoshida S. 1981 Fundamentals of Rice Crop Science, pp. 1-2. IRRI. Manila

Zahrah, S. 2011. Aplikasi pupuk bokashi dan npk organik pada tanah ultisol untuk tanaman padi sawah dengan sistem SRI (System of Rice Intensification). Jurnal Ilmu Lingkungan, 5(02), 11 